\title{
Article \\ Effects of Plant Growth Regulators and N Rate on the Morphological Traits of Generative Tillers and Seed Yields of Chewings and Strong Creeping Red Fescue
}

\author{
Małgorzata Szczepanek ${ }^{1, *} \mathbb{1}$, Maciej Baczyński ${ }^{1}$ and Radomir Graczyk ${ }^{2}$ \\ 1 Department of Agronomy, UTP University of Science and Technology, Kaliskiego 7 Street, \\ 85-796 Bydgoszcz, Poland; mbaczynski@wp.pl \\ 2 Department of Biology and Animal Environment, UTP University of Science and Technology, \\ Kaliskiego 7 Street, 85-796 Bydgoszcz, Poland; radomir.graczyk@utp.edu.pl \\ * Correspondence: malgorzata.szczepanek@utp.edu.pl; Tel.: +48-523-749-465
}

Citation: Szczepanek, M.; Baczyński,

M.; Graczyk, R. Effects of Plant

Growth Regulators and N Rate on the

Morphological Traits of Generative

Tillers and Seed Yields of Chewings and Strong Creeping Red Fescue.

Agronomy 2021, 11, 65. https://

doi.org/10.3390/agronomy11010065

Received: 5 November 2020

Accepted: 28 December 2020

Published: 30 December 2020

Publisher's Note: MDPI stays neutral with regard to jurisdictional clai$\mathrm{ms}$ in published maps and institutional affiliations.

Copyright: $\odot 2020$ by the authors. Licensee MDPI, Basel, Switzerland. This article is an open access article distributed under the terms and conditions of the Creative Commons Attribution (CC BY) license (https:// creativecommons.org/licenses/by/ $4.0 /)$.

\begin{abstract}
Plant growth regulators (PGRs) are used as a management tool to minimize plant height and subsequent stem lodging in grass seed crops. Their efficacy is influenced not only by the method of application, but also by the management and genetic variations within and between species. This aim of the study was to evaluate the effect of PGRs on morphological traits of generative tillers and seed yield of Festuca rubra L ssp. rubra (strong creeping red fescue) and F. $r$. L ssp. commutata (Chewings red fescue) under low and medium doses of spring nitrogen fertilization (40 and $70 \mathrm{~kg} \mathrm{~N} \mathrm{ha}^{-1}$ ). PGRs were applied as: chlormequat chloride (CCC) at BBCH 30-31; CCC at $\mathrm{BBCH} 30-31+$ ethephon (ET) at BBCH 37-39; CCC at BBCH 30-31 + trinexapac-ethyl (TE) at BBCH 37-39. All the application methods of PGRs resulted in the shortening of the second internode, and the sequential application of CCC with ET or TE also resulted in the shortening of the third internode. In each PGR treatment, the lodging index in the plant (canopy height to tiller length ratio) was higher than that of the control. PGRs had a beneficial effect on the seed yield. The greatest increase in the seed yield was recorded after the application of CCC+TE. No interaction between PGRs and spring N fertilization rates on the seed yield of red fescue. The increase in the dose of spring nitrogen fertilizer from 40 to $70 \mathrm{~kg} \mathrm{~N} \mathrm{ha}^{-1}$ resulted in a significant increase in yield. Seed yield of chewing red fescue cv. Dorosa was $29 \%$ higher than strong creeping red fescue cv. Nista, mainly due to an increase in the number of generative tillers.
\end{abstract}

Keywords: cultivar; internode; lodging; plant growth regulators; seed yield components

\section{Introduction}

Red fescue (Festuca rubra L.) is an important perennial grass widely used as a component of pastures and lawn mixtures. The extensive geographic distribution of this species is as a result of adaptation to several different environmental and management conditions especially low-input sites [1-5]. Due to the slow growth rate and good adaptation to nutrient-poor habitats, lawn cultivars of red fescue are useful for green areas of mediumintensive use [2]. Among the several genotypes of red fescue, strong creeping red fescue (F.r. ssp. rubra) and Chewings fescue (F.r. ssp. commutata) are commonly used in lawn applications [6]. Strong creeping red fescue can spread through rhizomes but has lower turfgrass quality. Chewings red fescue, on the other hand, has high aesthetic qualities, due to its thin leaf blade, blade density, and lower disease prevalence [6]. In addition to aesthetic qualities, the ability to reproduce is an essential feature of any cultivar. Red fescue cultivars, which develop more generative tillers are more productive in seed cultivation $[6,7]$.

The performance of grass seed crops depends not only on the genotype, but also on habitat and crop management. One of the most productive agro-technical treatments is nitrogen fertilization. In the seed cultivation of red fescue, nitrogen is applied in fall 
and spring seasons, in a single or split rate. Nitrogen applied in an autumn season stimulates the development of fall tillers, which after vernalization (in winter) will become generative [8]. The function of nitrogen used in the spring is to satisfy the nutritional needs of the generative tillers during the time from the start of growth to ripening. Nitrogen promotes the elongation of generative tillers as the main nutrient. High nitrogen levels, particularly in good soil moisture conditions, can increase the propensity of plants to lodge, which hinders harvesting and increases losses due to seed shattering, and may adversely affect the quality of the crop $[9,10]$.

Plant growth regulators (PGRs) are used in grass seed production to limit shoot height and regulate lodging [11,12]. Chemical plant growth regulators should only be used in healthy seed crops in good growing conditions [13]. It is especially justified to use PGRs with increased rates of spring $\mathrm{N}$ fertilization $[13,14]$. PGRs should be applied from the beginning of stem elongation to the beginning of earing (growth stages BBCH 32-50) [13]. PGRs reduce lodging by shortening and/or strengthening the internodes. They reduce elongation by inhibiting production of gibberellins (GA) or promoting biosynthesis of ethylene. Most PGRs act by inhibiting gibberellin (GA) biosynthesis, e.g., chlormequat chloride (CCC), which blocks the cyclases copalyl-diphosphate synthase and ent-kaurene synthase involved in the early steps of GA metabolism. Trinexapac-ethyl (TE), inparticular, blocks 3ss-hydroxylation, thereby inhibiting the formation of active GAs from inactive precursors [15]. Unlike other PGRs, ethephon (ET) does not inhibit the production of Gas, but results in the release of the gaseous plant hormone, ethylene. Increased ethylene allows the cells to reduce the elongation of the internode and increase the width instead [16].

To date, the few studies on the use of PGRs in seed cultivation of Lolium perenne L. [17], Dactylis glomerata L. [18,19], and Festuca arundinacea Schreb. [20] Concerned mainly TE, and less often paclobutrazole, CCC, or prohexadione-Ca. Further studies are needed to evaluate the interactions between $\mathrm{N}$ rates and spring PGR applications in the seed cultivation of diverse genotypes of red fescue [2].

The goal of our research was to determine the effect and correlation of the nitrogen rates applied in the spring (40 and $70 \mathrm{~kg} \mathrm{ha}^{-1}$ ) and the date and type of PGRs (CCC, TE, and ET) in shaping the morphological features of generative tillers determining the seed yield and the lodging of morphologically diverse forms of Chewings and strong creeping red fescue. It was believed, according to the research hypothesis, that the increase in the nitrogen rate applied in the spring would stimulate the growth and yield of the red fescue but may increase lodging. The application of PGRs, by modifying the morphological features of the generative tillers (length, diameter, and thickness of the internode wall) will limit lodging, and the effect of the action will depend on the genetically determined morphological properties of the red fescue subspecies.

\section{Materials and Methods}

\subsection{Experimental Site}

The study was based on field experiments located in Poland, in the KuyavianPomeranian region $\left(17^{\circ} 35^{\prime} \mathrm{E} ; 53^{\circ} 09^{\prime} \mathrm{N}\right)$. The soil at the experimental site is classified as mesic Typic Hapludalfs (USDA Soil Taxonomy). This soil is characterized by a high content of available $\mathrm{P}\left(65.0 \mathrm{mg} \mathrm{kg}^{-1}\right)$, medium content of $\mathrm{K}\left(145.2 \mathrm{mg} \mathrm{kg}^{-1}\right)$, a very low content of $\mathrm{Mg}\left(69 \mathrm{mg} \mathrm{g}^{-1}\right)$, a low content of organic carbon $\left(7.5-7.8 \mathrm{~g} \mathrm{~kg}^{-1}\right)$ and the inorganic nitrogen $\left(0.69-0.75 \mathrm{~g} \mathrm{~kg}^{-1} \mathrm{NH}_{4}-\mathrm{N}\right.$ and $\left.\mathrm{NO}_{3}-\mathrm{N}\right)$. Moreover, the soil is characterized by a slight acidic reaction ( $\mathrm{pH}$ in $1 \mathrm{~mol} \mathrm{KCL} \mathrm{5.7-6.1).} \mathrm{Detailed} \mathrm{characteristics} \mathrm{of} \mathrm{soil} \mathrm{conditions}$ can be found in the study by Szczepanek et al. [21].

The average annual precipitation at the experimental site (1980-2015) is $517 \mathrm{~mm}$ for thea long-term period (1980-2015) is $517 \mathrm{~mm}$, and the, while its mean air temperature is $8.4^{\circ} \mathrm{C}$. The mean air temperature from the start of the growing period to the ripening stage of the plant ( 1 March-31 July) was $10.9{ }^{\circ} \mathrm{C}$ in $2013 ; 13.3^{\circ} \mathrm{C}$ in 2014 , and $11.7^{\circ} \mathrm{C}$ in 2015. The total rainfall of the area in the same period was $248 \mathrm{~mm}, 256 \mathrm{~mm}$, and $156 \mathrm{~mm}$, re-spectively. 


\subsection{Experimental Design}

The study was based on two replicate experiments carried out in two fields of $500 \mathrm{~m}$ apart. The experiment was established in 2012, with seed production measured over two successive years (2013 and 2014). The entire experiment was repeated, re-established in 2013 and seed production yield was calculated in 2014 and 2015. Treatments with plant growth regulators (PGRs) (main plot, $60 \mathrm{~m}^{2}$ ) were as follows: (i) untreated control; (ii) CCC at BBCH 30-31 [18]; (iii) CCC at BBCH 30-31 + ET at BBCH 37-39; (iv) CCC at BBCH 30-31 + TE at BBCH 37-39 (Table 1). PCRs were applied using a hand sprayer as an aqueous solution $\left(300 \mathrm{dm}^{3}\right.$ of water ha $\left.{ }^{-1}\right)$. The doses of active ingredients (a.i.) are presented in Table 1. Two lawn cultivars of red fescue were used: Nista (Festuca rubra L ssp. rubra, strong creeping red fescue) and Dorosa (F. r. L ssp. commutata, Chewings red fescue) (subplots, $30 \mathrm{~m}^{2}$ ). Both cultivars are characterized by high aesthetic value in lawn use and high seed yields. Two nitrogen rates (40 and $70 \mathrm{~kg} \mathrm{ha}^{-1}$ ) were applied (sub-sub-plot, $15 \mathrm{~m}^{2}$ ) at the beginning of the growing season (in the last ten days of March).

Table 1. Experimental treatments.

\begin{tabular}{|c|c|c|}
\hline Plant Growth Regulator & Cultivar & Nitrogen Rate \\
\hline Control- without treatment & \multirow{3}{*}{$\begin{array}{c}\text { cv. Nista } \\
\text { strong creeping red fescue } \\
\text { Festuca rubra L ssp. rubra }\end{array}$} & \multirow{3}{*}{$40 \mathrm{~kg} \mathrm{ha}^{-1}$} \\
\hline $\begin{array}{c}\text { CCC-chloromequat chloride } 1350 \text { a.i. } \mathrm{g} \mathrm{ha}^{-1} \text {, at the beginning of stem } \\
\text { elongation stage }(\mathrm{BBCH} 30-31)\end{array}$ & & \\
\hline $\begin{array}{c}\text { CCC-chloromequat chloride } 625 \text { a.i. } \mathrm{g} \mathrm{ha}^{-1} \text {, at the beginning of stem elongation } \\
\text { stage }(\mathrm{BBCH} 30-31)\end{array}$ & & \\
\hline + ET-ethephon 240 a.i. $\mathrm{g} \mathrm{ha}^{-1}$, at flag the leaf stage (BBCH 37-39) & \multirow{3}{*}{$\begin{array}{l}\text { cv. Dorosa } \\
\text { Chewings red fescue } \\
\text { Festuca rubra L ssp. } \\
\text { commutata }\end{array}$} & \multirow{3}{*}{$70 \mathrm{~kg} \mathrm{ha}^{-1}$} \\
\hline $\begin{array}{c}\text { CCC-chloromequat chloride } 625 \text { a.i. } \mathrm{g} \mathrm{ha}^{-1} \text {, at the beginning of stem elongation } \\
\text { stage }(\mathrm{BBCH} 30-39)\end{array}$ & & \\
\hline + TE-trinexapac-ethyl 75 a.i. $\mathrm{g} \mathrm{ha}^{-1}$, at the flag leaf stage (BBCH 37-39) & & \\
\hline
\end{tabular}

\subsection{Crop Management}

Red fescue was sown at the beginning of April in an amount of $10 \mathrm{~kg} \mathrm{ha}^{-1}$, as an under sown crop into spring barley. The sowing depth was between 1 and $2 \mathrm{~cm}$, and the row spacing of red fescue amounted to $24 \mathrm{~cm}$. After the harvest of barley (in the establishment year) or the harvest of red fescue seeds in the first production year, the rates of mineral fertilization were: $\mathrm{N} 20 \mathrm{~kg} \mathrm{ha}^{-1}, \mathrm{P} 26 \mathrm{~kg} \mathrm{ha}^{-1}$, and $\mathrm{K} 66 \mathrm{~kg} \mathrm{ha}^{-1}$. Weed control was performed in fall in the establishment year and first production year. The type and doses of herbicides are provided in the article by Szczepanek et al. (2020). In the first and the second production years, during the start of red fescue growth, nitrogen (ammonium nitrate) was applied at rates 40 or $70 \mathrm{~kg} \mathrm{ha}^{-1}$.

\subsection{Measurement}

Internode length, diameter, and wall thickness were determined based on measurements made at flowering, on 50 randomly selected tillers from each plot. The length of each internode was measured using a ruler. Internode diameter and internode wall thickness measurements were taken at the center of each internode using a caliper. The number of generative tillers per $\mathrm{m}^{2}$ was determined at the flowering stage, based on tillers taken from the length of the row corresponding to $0.5 \mathrm{~m}^{2}$ of the area. At the same stage of development, the length of the panicle and the number of spikelets per panicle were calculated on the basis of 50 randomly selected tillers from each plot. The number of flowers per spikelet was calculated on the same inflorescences by measuring three spikelets, one from the lower, middle, and upper sections of each panicle. In a similar manner, the number of seeds per spikelet was determined on 30 panicles taken from each plot just before harvesting (at the ripening stage). The lodging index was expressed as the ratio of the canopy height to the length of the generative tillers (\%), based on field measurements made twice: at 
flowering and just before seed harvest (at the end of ripening stage), one per $2 \mathrm{~m}^{2}$ of each plot. The yield of seed and straw was calculated on the basis of the yield of each plot $\left(15 \mathrm{~m}^{2}\right)$, which was converted to a constant humidity of $15 \%$. Plots were harvested using a combine harvester (Wintersteiger Nursery Master, Ried, Austria). Thousand seed weight (TSW) was calculated 2-3 months after harvest on the basis of 200 seeds per plot.

\subsection{Statistical Analysis}

The basic statistical descriptors included mean values $\bar{x}$ and standard deviation $( \pm \mathrm{SD})$. To improve normality and homogeneity of variance, data were log-transformed [22,23]. Residuals were tested for heteroscedasticity and normality using Levene's test and KolmogorovSmirnov test. Within the framework of a general linear model (GLM), these dependent variables were analyzed by repeated measures four-factor randomized complete block multivariate analyses of variance with PGR (Control, CCC; CCC+ET; CCC+TE) as repeated factor and block $(1,2)$ being nested in cultivars of red fescue (Nista, Dorosa) and the rates of $\mathrm{N}$ mineral fertilization ( 40 and $70 \mathrm{~kg} \mathrm{~N} \mathrm{ha}^{-1}$ ). Fixed factors were cultivars and $\mathrm{N}$ rates. As part of the multivariate analyses of variance repeated general linear models (GLM; type III sum of squares) were provided between and within subject effects and the significant variations were provided between sampling plant growth regulator. To further analyze the significant effects of multivariate analyses of variance individual ANOVAs for each sampling PGR were performed. Tukey's post hoc test was used to identify significant differences between means [24]. The paper presents the means for two seed production years for two "replicate" experiments. No significant interactions of PGRs and cultivars and $\mathrm{N}$ fertilization rates were found, therefore only mean values of the analyzed biometric traits of tillers, seed yield, and yield components were included.

Canonical correspondence analysis (CCA) was used to visualize and identify factors correlating with seed yield, generative tillers, spikelets per panicle, seeds per spikelet, and TSW of Festuca rubra ssp. rubra cv. Nista and F. $r$. ssp. commutata cv. Dorosa depending on plant growth regulator and nitrogen fertilization rate (CCA) $[25,26]$. Monte Carlopermutation test was uses for testing the significance of canonical axes $[27,28]$. Further, we used linear regression to relate plant growth regulator, nitrogen fertilization rate, and internode length to internode diameter and internode wall thickness and of Festuca rubra ssp. rubra cv. Nista and F. r. ssp. commutata cv. Dorosa [29]. In these regression analyses, each biometric trait is represented by a single data point. The level of significance for all statistical tests was accepted at $\alpha=0.05$. The statistical calculations mentioned earlier were carried out with MS Excel 2019 software (Microsoft, Redmond, WA, USA, 2019), STATISTICA 13.3 (Dell, Round Rock, TX, USA, 2019), CANOCO 4.5 (Microcomputer Power, Ithaca, NY, USA, Microsoft), and MVSP 3.2 (Multi Variate Statistical Package, Kovach Computing Services 2019) software.

\section{Results}

\subsection{Morphological Traits of Generative Tillers}

The morphological traits of generative tillers, such as the length, diameter, and wall thickness, depended to a greater extent on the PGR applied and the red fescue cultivar than on the spring nitrogen fertilization rate (Table 2). The first internode was significantly shorter $(p=0.003)$ after the application of CCC or CCC+TE compared to the control (Table 3). All methods of PGR applications (CCC; CCC+ET; CCC+TE) caused a significant $(p<0.001)$ shortening of the second internode. Only sequential application of PRGs (CCC at BBCH 30-31 + ET or TE at BBCH 37-39) resulted in a significant $(p=0.003)$ shortening of the third internode. PGR application had no effect on the length of the fourth internode. The first and second internodes were significantly longer $(p<0.001)$ in $\mathrm{cv}$. Nista (strong creeping red fescue), while the third internode $(p=0.038)$ in cv. Dorosa (Chewings red fescue). The tested cultivars were characterized by a similar length of the fourth internode. 


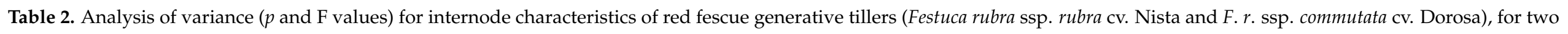
production years and two field experiments.

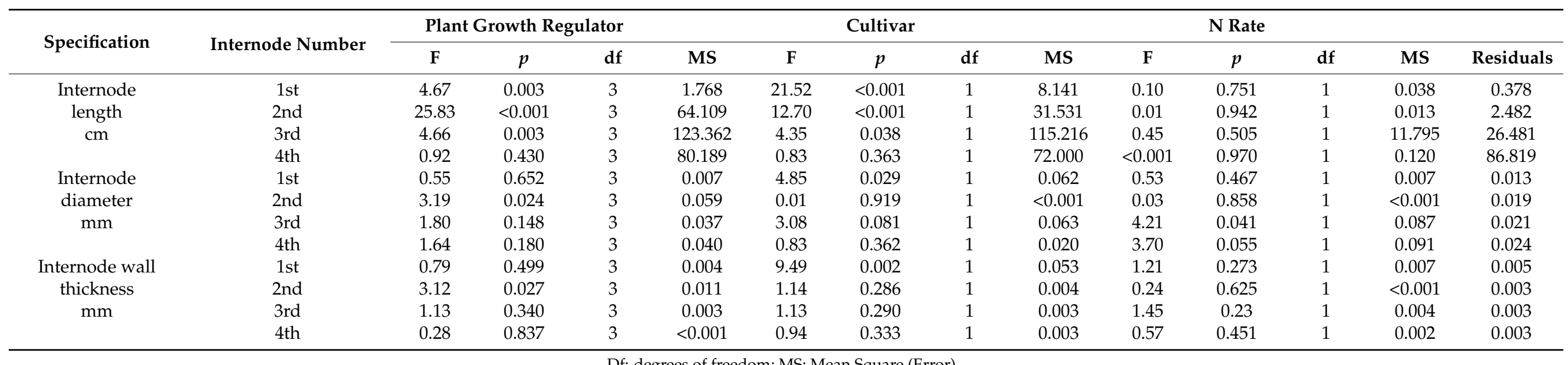

Df: degrees of freedom; MS: Mean Square (Error).

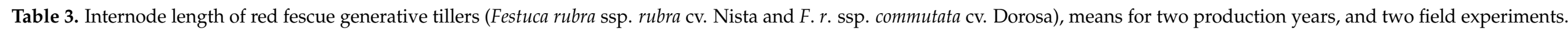

\begin{tabular}{|c|c|c|c|c|c|}
\hline \multicolumn{2}{|c|}{ Treatment } & \multirow{2}{*}{$\begin{array}{c}\text { 1st Internode Length cm } \\
2.23 \pm 0.75 \mathrm{a}\end{array}$} & \multirow{2}{*}{$\begin{array}{c}\text { 2nd Internode Length cm } \\
9.49 \pm 1.78 \mathrm{a}\end{array}$} & \multirow{2}{*}{$\frac{\text { 3rd Internode Length cm }}{21.5 \pm 5.57 \mathrm{a}}$} & \multirow{2}{*}{$\begin{array}{c}\text { 4th Internode Length } \mathrm{cm} \\
34.2 \pm 9.50 \mathrm{a}\end{array}$} \\
\hline PGR & Control & & & & \\
\hline & $\mathrm{CCC}$ & $1.92 \pm 0.49 \mathrm{~b}$ & $7.58 \pm 1.36 \mathrm{~b}$ & $19.8 \pm 5.49 \mathrm{ab}$ & $31.9 \pm 8.92 \mathrm{a}$ \\
\hline & $\mathrm{CCC}+\mathrm{ET}$ & $2.10 \pm 0.72 \mathrm{ab}$ & $7.76 \pm 1.55 b$ & $18.6 \pm 5.22 b$ & $32.9 \pm 8.80 \mathrm{a}$ \\
\hline & $\mathrm{CCC}+\mathrm{TE}$ & $1.87 \pm 0.56 \mathrm{~b}$ & $7.25 \pm 1.73 b$ & $18.6 \pm 4.62 \mathrm{~b}$ & $31.7 \pm 9.43 \mathrm{a}$ \\
\hline \multirow{2}{*}{ Cultivar } & Nista & $2.21 \pm 0.70 \mathrm{a}$ & $8.37 \pm 1.57 \mathrm{a}$ & $19.0 \pm 4.57 \mathrm{~b}$ & $32.2 \pm 8.94 \mathrm{a}$ \\
\hline & Dorosa & $1.85 \pm 0.54 \mathrm{~b}$ & $7.67 \pm 2.00 \mathrm{~b}$ & $20.3 \pm 5.96 \mathrm{a}$ & $33.2 \pm 9.38 \mathrm{a}$ \\
\hline $\mathrm{N}$ rate & 40 & $2.04 \pm 0.70 \mathrm{a}$ & $8.03 \pm 1.79 \mathrm{a}$ & $19.8 \pm 5.86 \mathrm{a}$ & $32.7 \pm 9.64 \mathrm{a}$ \\
\hline $\mathrm{kg} \mathrm{ha}^{-1}$ & 70 & $2.02 \pm 0.60 \mathrm{a}$ & $8.01 \pm 1.87 \mathrm{a}$ & $19.4 \pm 4.79 \mathrm{a}$ & $32.6 \pm 8.70 \mathrm{a}$ \\
\hline
\end{tabular}

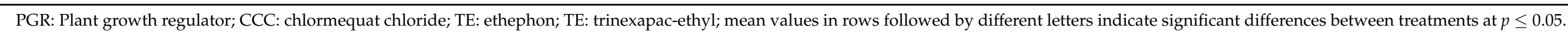


The experimental factors had little effect on the diameter of the subsequent internodes (Table 4). The diameters of the first, third and fourth internodes were similar after the application of PGR and in the control. The diameter of the second internode was significantly larger $(p=0.024)$ compared to the control only after the sequential application of CCC+TE. The cultivar Nista was characterized by a significantly larger diameter $(p=0.029)$ of the first internode than the $\mathrm{cv}$. Dorosa. Increasing the spring $\mathrm{N}$ rate from 40 to $70 \mathrm{~kg} \mathrm{~N} \mathrm{ha}^{-1}$ resulted in a significant increase in the diameter of the third internode $(p=0.041)$ and a slight increase in the diameter of the fourth internode.

Table 4. Internode diameter of red fescue generative tillers (Festuca rubra ssp. rubra cv. Nista and F. $r$. ssp. commutata cv. Dorosa), means for two production years, and two field experiments.

\begin{tabular}{|c|c|c|c|c|c|}
\hline \multicolumn{2}{|c|}{ Treatment } & \multirow{2}{*}{$\begin{array}{c}\begin{array}{c}\text { 1st Internode } \\
\text { Diameter mm }\end{array} \\
0.900 \pm 0.109 \mathrm{a}\end{array}$} & \multirow{2}{*}{$\begin{array}{c}\text { 2nd Internode } \\
\text { Diameter mm }\end{array}$} & \multirow{2}{*}{$\begin{array}{c}\begin{array}{c}\text { 3rd Internode } \\
\text { Diameter mm }\end{array} \\
0.851 \pm 0.155 \mathrm{a}\end{array}$} & \multirow{2}{*}{$\begin{array}{c}\begin{array}{c}\text { 4th Internode } \\
\text { Diametermm }\end{array} \\
0.651 \pm 0.172 \mathrm{a}\end{array}$} \\
\hline PGR & Control & & & & \\
\hline & CCC & $0.921 \pm 0.110 \mathrm{a}$ & $0.977 \pm 0.143 \mathrm{ab}$ & $0.876 \pm 0.152 \mathrm{a}$ & $0.688 \pm 0.146 \mathrm{a}$ \\
\hline & $\mathrm{CCC}+\mathrm{ET}$ & $0.923 \pm 0.129 a$ & $0.995 \pm 0.131 \mathrm{ab}$ & $0.883 \pm 0.134 \mathrm{a}$ & $0.695 \pm 0.137 \mathrm{a}$ \\
\hline & $\mathrm{CCC}+\mathrm{TE}$ & $0.915 \pm 0.100 \mathrm{a}$ & $1.014 \pm 0.132 \mathrm{a}$ & $0.909 \pm 0.140 \mathrm{a}$ & $0.677 \pm 0.167 \mathrm{a}$ \\
\hline \multirow{2}{*}{ Cultivar } & Nista & $0.930 \pm 0.111 \mathrm{a}$ & $0.983 \pm 0.139 a$ & $0.896 \pm 0.151 \mathrm{a}$ & $0.695 \pm 0.168 \mathrm{a}$ \\
\hline & Dorosa & $0.899 \pm 0.112 b$ & $0.982 \pm 0.132 \mathrm{a}$ & $0.864 \pm 0.140 \mathrm{a}$ & $0.677 \pm 0.145 \mathrm{a}$ \\
\hline $\mathrm{N}$ rate & 40 & $0.920 \pm 0.105 \mathrm{a}$ & $0.984 \pm 0.138 \mathrm{a}$ & $0.861 \pm 0.149 \mathrm{~b}$ & $0.667 \pm 0.158 \mathrm{a}$ \\
\hline $\mathrm{kg} \mathrm{ha}^{-1}$ & 70 & $0.910 \pm 0.120 \mathrm{a}$ & $0.981 \pm 0.133 \mathrm{a}$ & $0.898 \pm 0.141 \mathrm{a}$ & $0.704 \pm 0.154 \mathrm{a}$ \\
\hline
\end{tabular}

PGR: Plant growth regulator; CCC: chlormequat chloride; TE: ethephon; TE: trinexapac-ethyl; mean values in rows followed by different letters indicate significant differences between treatments at $p \leq 0.05$.

The internode wall thickness was significantly affected by the application of PRG and the genetic traits of the cultivar, while no effect of the nitrogen fertilization rate was found (Table 5). The wall thicknesses of the first, third, and fourth internodes were similar after the application of PGR and in the control. The thickness of the second internode was positively affected by the sequential application of CCC+ET. Only for the first internode was the wall thickness greater in the strong creeping red fescue cultivar Nista than in the Chewings red fescue cv. Dorosa.

Table 5. Internode wall thickness of red fescue generative tillers (Festuca rubra ssp. rubra cv. Nista and F. r. ssp. commutata cv. Dorosa), means for two production years, and two field experiments.

\begin{tabular}{|c|c|c|c|c|c|}
\hline \multicolumn{2}{|c|}{ Treatment } & \multirow{2}{*}{$\begin{array}{c}\text { 1st Internode Wall } \\
\text { Thickness mm }\end{array}$} & \multirow{2}{*}{$\begin{array}{c}\begin{array}{c}\text { 2nd Internode } \\
\text { Wall Thickness } \\
\text { mm }\end{array} \\
0.170 \pm 0.058 \mathrm{~b}\end{array}$} & \multirow{2}{*}{$\begin{array}{c}\begin{array}{c}\text { 3rd Internode } \\
\text { Wall Thickness } \\
\text { mm }\end{array} \\
0.147 \pm 0.051 \mathrm{a}\end{array}$} & \multirow{2}{*}{$\begin{array}{c}\begin{array}{c}\text { 4th Internode } \\
\text { Wall Thickness } \\
\text { mm }\end{array} \\
0.123 \pm 0.055 \mathrm{a}\end{array}$} \\
\hline PGR & Control & & & & \\
\hline & CCC & $0.212 \pm 0.072 \mathrm{a}$ & $0.184 \pm 0.053 \mathrm{ab}$ & $0.159 \pm 0.051 \mathrm{a}$ & $0.129 \pm 0.057 \mathrm{a}$ \\
\hline & $\mathrm{CCC}+\mathrm{ET}$ & $0.229 \pm 0.082 a$ & $0.199 \pm 0.063 \mathrm{a}$ & $0.158 \pm 0.057 \mathrm{a}$ & $0.128 \pm 0.057 \mathrm{a}$ \\
\hline & $\mathrm{CCC}+\mathrm{TE}$ & $0.223 \pm 0.078 \mathrm{a}$ & $0.195 \pm 0.062 \mathrm{ab}$ & $0.164 \pm 0.052 \mathrm{a}$ & $0.132 \pm 0.060 \mathrm{a}$ \\
\hline \multirow[b]{2}{*}{ Cultivar } & Nista & $0.234 \pm 0.079 a$ & $0.191 \pm 0.063 \mathrm{a}$ & $0.160 \pm 0.056 \mathrm{a}$ & $0.132 \pm 0.063 \mathrm{a}$ \\
\hline & Dorosa & $0.205 \pm 0.071 b$ & $0.183 \pm 0.056 \mathrm{a}$ & $0.153 \pm 0.049 \mathrm{a}$ & $0.125 \pm 0.050 \mathrm{a}$ \\
\hline $\mathrm{N}$ rate & 40 & $0.214 \pm 0.077 \mathrm{a}$ & $0.185 \pm 0.058 \mathrm{a}$ & $0.153 \pm 0.052 \mathrm{a}$ & $0.125 \pm 0.057 \mathrm{a}$ \\
\hline $\mathrm{kg} \mathrm{ha}^{-1}$ & 70 & $0.225 \pm 0.076 \mathrm{a}$ & $0.189 \pm 0.061 \mathrm{a}$ & $0.161 \pm 0.053 \mathrm{a}$ & $0.131 \pm 0.057 \mathrm{a}$ \\
\hline
\end{tabular}

PGR: Plant growth regulator; CCC: chlormequat chloride; TE: ethephon; TE: trinexapac-ethyl; mean values in rows followed by different letters indicate significant differences between treatments at $p \leq 0.05$.

Figure 1 shows that significant correlation coefficients indicate a relationship between the length, diameter, and wall thickness of each successive internode. As a given internode lengthened, its diameter and wall thickness decreased. However, the average reduction rate of the internode wall thickness per unit of increase in its length was 2.5 times greater that of its diameter. A $1 \mathrm{~cm}$ increase in the internode length resulted to a 3.8, 1.0, 0.8, and 
$0.9 \%$ decrease in diameter, respectively, for the first, second, and third internodes. For the wall thickness, the reduction was 9.7, 3.5, 1.8, and 1.6\%, respectively. For the first internode, within the range of its length from 0.4 to $5.4 \mathrm{~cm}$ (minimum and maximum value), its diameter decreased by $19 \%$ and the wall thickness by $48 \%$. Within the range of the length of the second internode from 4 to $14 \mathrm{~cm}$, its diameter decreased by $10 \%$ and the wall thickness by $35 \%$. Within the range of the length of the third internode from 8 to $40 \mathrm{~cm}$, its diameter decreased by $25.6 \%$ and the wall thickness by $57.6 \%$. Within the range of the length of the fourth internode from 12 to $52 \mathrm{~cm}$, its diameter decreased by $36 \%$ and the wall thickness by $64 \%$.
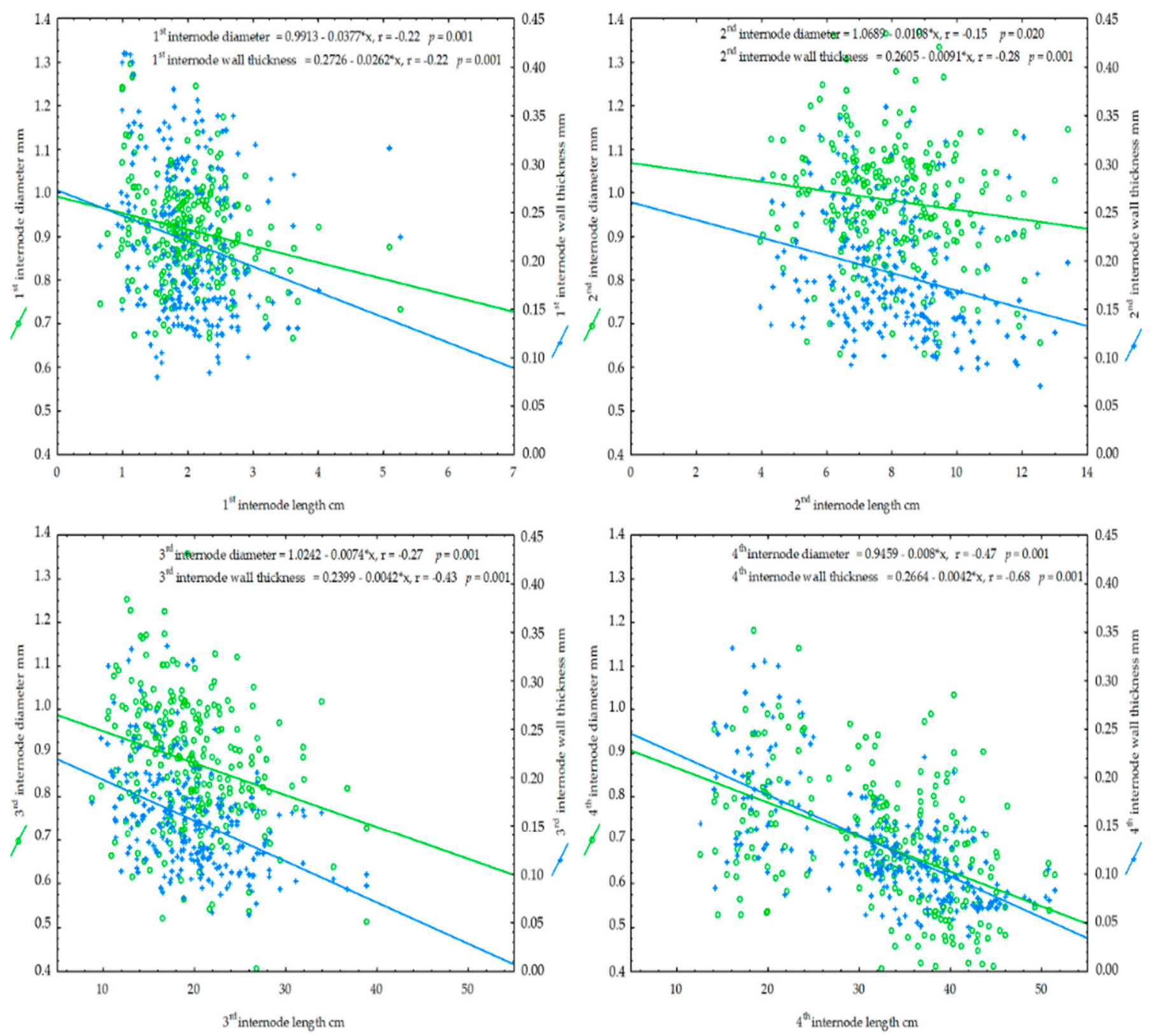

Figure 1. Relationship between length and diameter and wall thickness of successive internodes of red fescue (Festuca rubra ssp. rubra cv. Nista and F.r. ssp. commutata cv. Dorosa).

Table 6 shows the significant relationship between the length of successive internodes and the lodging index. The increase in the length of the second, third and fourth internodes caused an increase in lodging (a decrease of canopy height to tiller length ratio). However, no such relationship was found for the first internode. Negative values of the correlation 
coefficients for the diameter of the first and second internodes indicate that with a larger diameter of the lower internodes the lodging index is smaller. On the other hand, positive significant values of the correlation coefficients indicate that increasing the diameter of the fourth internode as well as the wall thickness of the third and fourth internodes increases the lodging index.

Table 6. Relationship (correlation coefficient) between lodging index (canopy height to tiller length ratio) at ripening and length, diameter, and a wall thickness of successive internodes of red fescue (Festuca rubra ssp. rubra cv. Nista and F. r. ssp. commutata cv. Dorosa).

\begin{tabular}{cccccc}
\hline \multicolumn{2}{c}{ Internode Length } & \multicolumn{2}{c}{ Internode Diameter } & \multicolumn{2}{c}{ Internode Wall Thickness } \\
\hline $\begin{array}{c}\text { Successive } \\
\text { Internode }\end{array}$ & $\mathbf{r}(\boldsymbol{X}, \mathbf{Y}) ; \boldsymbol{p}$ & $\begin{array}{l}\text { Successive } \\
\text { Internode }\end{array}$ & $\mathbf{r}(\boldsymbol{X}, \mathbf{Y}) ; \boldsymbol{p}$ & $\begin{array}{l}\text { Successive } \\
\text { Internode }\end{array}$ & $\mathbf{r}(\boldsymbol{X}, \mathbf{Y}) ; \boldsymbol{p}$ \\
\hline 1st & $0.2066 ; p=0.001$ & 1st & $-0.2760 ; p<0.001$ & 1 st & $0.1201 ; p=0.055$ \\
2nd & $-0.1753 ; p=0.005$ & 2nd & $-0.1707 ; p=0.006$ & 2 nd & $0.0024 ; p=0.969$ \\
3rd & $-0,3679 ; p<0.001$ & 3rd & $0.0407 ; p=0.663$ & 3rd & $0.2505 ; p<0.001$ \\
4th & $-0.5205 ; p<0.001$ & 4th & $0.1984 ; p=0.001$ & 4 th & $0.3638 ; p<0.001$ \\
\hline
\end{tabular}

\subsection{Seed Yield and Yield Components}

The use of growth regulators, the genetic properties of the cultivar and the spring nitrogen fertilization rate had a significant impact on the yield of red fescue seeds (Table 7). The use of CCC or CCC + TE caused a significant $(p=0.002)$ increase in seed yield compared to the control (Table 8). The effect of sequential application of CCC+TE on seed yield was also favorable, but not statistically significant. In contrast, the straw weight after the application of CCC+TE was significantly $(p=0.001)$ lower than that untreated with PGRs. The average seed yield of Chewings red fescue cv. Dorosa for PCR and N rate was significantly $(p<0.001)$ higher than that of strong creeping red fescue cv. Nista. In contrast, the straw weight was significantly $(p<0.001)$ higher in cv. Nista. Increasing the rate of spring nitrogen fertilization from 40 to $70 \mathrm{~kg} \mathrm{~N} \mathrm{ha}^{-1}$ resulted in, on average for PGRs and cultivars, a significant increase in seed yield $(p<0.001)$, and the straw yield $(p=0.027)$.

During the flowering period, red fescue had a high lodging index (the canopy height to tiller length ratio); $93.3 \%$ on average (Table 8). Just before harvest (at the ripening stage), this lodging index was much lower and averaged $75.8 \%$. Red fescue treated with PGRs, regardless of the application method, had a significantly higher lodging index $(p<0.001)$ than in the control, both at the flowering and maturation stage. At both of these development stages, the lodging index of Chewings red fescue cv. Dorosa was significantly larger $(p<0.001)$ than that of strong creeping red fescue cv. Nista. Moreover, increasing the rate of nitrogen fertilization from 40 to $70 \mathrm{~kg} \mathrm{ha}^{-1}$ resulted in a significant $(p<0.001)$ reduction in the lodging index.

Among the tested experimental factors, only the genetic properties of the cultivars had a significant $(p<0.001)$ effect on generative tiller density. On average, for PGRs and N rates, cv. Dorosa developed significantly more such tillers than cv. Nista. 


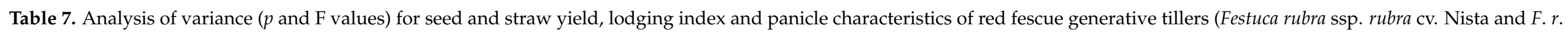
ssp. commutata cv. Dorosa), for two production years and two field experiments.

\begin{tabular}{|c|c|c|c|c|c|c|c|c|c|c|c|c|}
\hline \multirow{2}{*}{ Specification } & \multicolumn{3}{|c|}{ PGR } & \multicolumn{4}{|c|}{ Cultivar } & \multicolumn{5}{|c|}{ N Rate } \\
\hline & $\mathbf{F}$ & $p$ & df & MS & $\mathbf{F}$ & $p$ & df & MS & $\mathbf{F}$ & $p$ & df & MS \\
\hline Seed yield, $\mathrm{Mg} \mathrm{ha}^{-1}$ & 5.07 & 0.002 & 3 & 0.221 & 108.49 & $<0.001$ & 1 & 4.734 & 16.19 & $<0.001$ & 1 & 0.706 \\
\hline Straw yield, $\mathrm{Mg} \mathrm{ha}^{-1}$ & 3.79 & 0.011 & 3 & 11.384 & 16.83 & $<0.001$ & 1 & 50.508 & 4.93 & 0.027 & 1 & 14.800 \\
\hline Lodging at flowering, $\%$ & 12.50 & $<0.001$ & 3 & 1387.353 & 12.46 & $<0.001$ & 1 & 1383.163 & 24.77 & $<0.001$ & 1 & 2749.838 \\
\hline Lodging at ripening, \% & 24.73 & $<0.001$ & 3 & 6041.687 & 10.52 & 0.001 & 1 & 2570.657 & 11.07 & 0.001 & 1 & 2705.206 \\
\hline Generative tillers, no $\mathrm{m}^{-2}$ & 1.39 & 0.248 & 3 & $550,645.83$ & 312.96 & $<0.001$ & 1 & $124,379,742.23$ & 3.39 & 0.067 & 1 & $1,346,589.687$ \\
\hline Panicle length, $\mathrm{cm}$ & 7.85 & $<0.001$ & 3 & 8.949 & 251.49 & $<0.001$ & 1 & 286.539 & 14.41 & $<0.001$ & 1 & 16.421 \\
\hline Spikelets, no panicle -1 & 4.56 & 0.004 & 3 & 69.551 & 2.95 & 0.087 & 1 & 44.993 & 31.86 & $<0.001$ & 1 & 486.415 \\
\hline Florets, no spikelet ${ }^{-1}$ & 1.79 & 0.149 & 3 & 1.061 & 4.59 & 0.033 & 1 & 2.718 & $<0.01$ & 0.958 & 1 & 0.002 \\
\hline Seeds, no spikelet ${ }^{-1}$ & 1.22 & 0.302 & 3 & 0.422 & 5.56 & 0.019 & 1 & 1.920 & 0.89 & 0.346 & 1 & 0.307 \\
\hline TSW, $\mathrm{g}$ & 24.50 & $<0.001$ & 3 & 0.372 & 10.66 & 0.001 & 1 & 0.162 & 0.02 & 0.901 & 1 & $<0.001$ \\
\hline
\end{tabular}

Df: degrees of freedom; MS: Mean Square (Error).

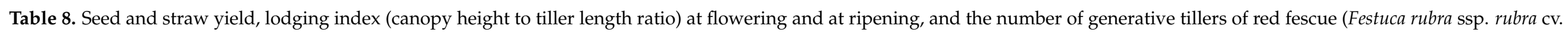

Nista and F.r. ssp. commutata cv. Dorosa), means for two production years, and two field experiments.

\begin{tabular}{|c|c|c|c|c|c|c|}
\hline \multicolumn{2}{|c|}{ Treatment } & \multirow{2}{*}{$\begin{array}{c}\text { Seed Yield } \mathbf{M g ~ h a}^{-1} \\
0.97 \pm 0.22 \mathrm{~b}\end{array}$} & \multirow{2}{*}{$\begin{array}{c}\text { Straw Yield } \mathbf{M g ~ h a} \mathbf{~}^{-1} \\
5.07 \pm 2.02 \mathrm{a}\end{array}$} & \multirow{2}{*}{$\begin{array}{c}\text { Lodging Index at Flowering \% } \\
84.8 \pm 14.9 \mathrm{~b}\end{array}$} & \multirow{2}{*}{$\begin{array}{c}\text { Lodging Index at Ripening \% } \\
61.4 \pm 17.7 \mathrm{~b}\end{array}$} & \multirow{2}{*}{$\begin{array}{c}\text { Generative Tillers No } \mathbf{~ m}^{-2} \\
2325 \pm 903 \mathrm{a}\end{array}$} \\
\hline PGR & Control & & & & & \\
\hline & CCC & $1.09 \pm 0.26 \mathrm{a}$ & $4.42 \pm 1.81 \mathrm{ab}$ & $93.8 \pm 7.8 \mathrm{a}$ & $80.6 \pm 14.6 \mathrm{a}$ & $2443 \pm 876 a$ \\
\hline & $\mathrm{CCC}+\mathrm{ET}$ & $1.10 \pm 0.26 \mathrm{a}$ & $4.48 \pm 1.72 \mathrm{ab}$ & $94.8 \pm 12.2 \mathrm{a}$ & $79.0 \pm 16.0 \mathrm{a}$ & $2540 \pm 978 a$ \\
\hline & $\mathrm{CCC}+\mathrm{TE}$ & $1.06 \pm 0.26 \mathrm{ab}$ & $4.05 \pm 1.53 \mathrm{~b}$ & $93.6 \pm 8.6 \mathrm{a}$ & $82.3 \pm 15.9 \mathrm{a}$ & $2451 \pm 991 \mathrm{a}$ \\
\hline \multirow{2}{*}{ Cultivar } & Nista & $0.92 \pm 0.26 \mathrm{~b}$ & $4.950 \pm 2.08 \mathrm{a}$ & $89.5 \pm 12.6 b$ & $72.7 \pm 16.8 b$ & $1754 \pm 808 b$ \\
\hline & Dorosa & $1.19 \pm 0.17 \mathrm{a}$ & $4.062 \pm 1.35 \mathrm{~b}$ & $94.1 \pm 10.6 \mathrm{a}$ & $79.0 \pm 18.9 \mathrm{a}$ & $3148 \pm 357 a$ \\
\hline $\mathrm{N}$ rate & 40 & $1.01 \pm 0.25 b$ & $4.266 \pm 1.67 \mathrm{~b}$ & $95.1 \pm 9.4 \mathrm{a}$ & $79.1 \pm 17.8 \mathrm{a}$ & $2378 \pm 924 a$ \\
\hline $\mathrm{kg} \mathrm{ha}^{-1}$ & 70 & $1.11 \pm 0.26 \mathrm{a}$ & $4.747 \pm 1.90 \mathrm{a}$ & $88.5 \pm 13.1 b$ & $72.6 \pm 17.9 \mathrm{~b}$ & $2523 \pm 946 a$ \\
\hline
\end{tabular}

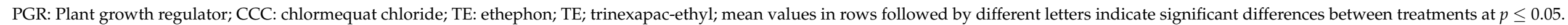


Table 9 shows that in each PCRs treatment, the panicle was significantly $(p<0.001)$ longer than in the control (Table 9). A beneficial effect of the application of PGRs on the number of spikelets per panicle was also observed, but the difference in relation to the control was statistically significant $(p=0.004)$ only after the application of CCC+TE. Application of PGRs had no effect on the number of florets per spikelet or seeds per spikelet. On the other hand, TSW was significantly $(p<0.001)$ higher after the application of PGRs than without the application. The cultivars differed significantly in their panicle traits. Nista had a significantly longer panicle $(p<0.001)$, developed more florets per spikelet $(p=0.033)$ and seeds per spikelet $(p=0.019)$, and the TSW of this cultivar was significantly higher $(p=0.001)$ than that of Dorosa. Increasing the spring rate of nitrogen fertilization increased the panicle length and the number of spikelets per panicle but had no significant effect on the number of florets and seeds per spikelet or on TSW.

Table 9. Panicle characteristics (panicle length, number of spikelets, number of florets and number of seeds per spikelet) and 1000-seed weight of red fescue (Festuca rubra ssp. rubra cv. Nista and F. r. ssp. commutata cv. Dorosa), means for two production years, and two field experiments.

\begin{tabular}{ccccccc}
\hline \multicolumn{2}{c}{ Treatment } & $\begin{array}{c}\text { Panicle } \\
\text { Length cm }\end{array}$ & $\begin{array}{c}\text { Spikelets } \\
\text { No Panicle }\end{array}$ & $\begin{array}{c}\text { Florets } \\
\text { No Spikelet }^{-1}\end{array}$ & $\begin{array}{c}\text { Seeds } \\
\text { No Spikelet }^{-1}\end{array}$ & TSW g \\
\hline PGR & Control & $8.89 \pm 2.56 \mathrm{~b}$ & $24.9 \pm 3.95 \mathrm{~b}$ & $3.53 \pm 0.66 \mathrm{a}$ & $2.42 \pm 0.60 \mathrm{a}$ & $0.87 \pm 0.18 \mathrm{~b}$ \\
& CCC & $9.64 \pm 1.61 \mathrm{a}$ & $26.1 \pm 4.04 \mathrm{ab}$ & $3.71 \pm 0.79 \mathrm{a}$ & $2.55 \pm 0.58 \mathrm{a}$ & $1.00 \pm 0.10 \mathrm{a}$ \\
& CCC + ET & $9.72 \pm 1.35 \mathrm{a}$ & $26.5 \pm 3.45 \mathrm{ab}$ & $3.65 \pm 0.71 \mathrm{a}$ & $2.57 \pm 0.56 \mathrm{a}$ & $1.03 \pm 0.10 \mathrm{a}$ \\
& CCC + TE & $9.51 \pm 1.57 \mathrm{a}$ & $27.5 \pm 5.06 \mathrm{a}$ & $3.84 \pm 0.87 \mathrm{a}$ & $2.61 \pm 0.58 \mathrm{a}$ & $1.01 \pm 0.10 \mathrm{a}$ \\
Cultivar & Nista & $10.50 \pm 1.11 \mathrm{a}$ & $26.7 \pm 4.55 \mathrm{a}$ & $3.79 \pm 0.67 \mathrm{a}$ & $2.63 \pm 0.52 \mathrm{a}$ & $1.00 \pm 0.12 \mathrm{a}$ \\
N rate & Dorosa & $8.38 \pm 1.15 \mathrm{~b}$ & $25.8 \pm 3.88 \mathrm{a}$ & $3.58 \pm 0.84 \mathrm{~b}$ & $2.45 \pm 0.63 \mathrm{~b}$ & $0.95 \pm 0.15 \mathrm{~b}$ \\
$\mathrm{~kg} \mathrm{ha}^{-1}$ & 40 & $9.18 \pm 1.16 \mathrm{~b}$ & $24.9 \pm 3.66 \mathrm{~b}$ & $3.69 \pm 0.74 \mathrm{a}$ & $2.50 \pm 0.59 \mathrm{a}$ & $0.98 \pm 0.15 \mathrm{a}$ \\
\hline
\end{tabular}

PGR: Plant growth regulator; CCC: chlormequat chloride; TE: ethephon; TE: trinexapac-ethyl; mean values in rows followed by different letters indicate significant differences between treatments at $p \leq 0.05$.

Canonical correspondence analysis (CCA) shows that the seed yield and yield components are significantly influenced by the cultivar $(p=0.001)$, while the effect of the rate of spring nitrogen fertilization is of secondary importance $(p=0.135)$ (Figure 2). The gradient represented by the first ordination axis significantly differentiates the seed yield and yield components against the background of PGRs application, nitrogen fertilization, and fescue cultivars. Two dimensions account for as much as $98.3 \%$ of the overall variability of the yield tested and its components. Lack of application of PRGs (control) has a greater impact on the traits tested in cv. Nista, both when fertilized with 40 and $70 \mathrm{~kg} \mathrm{~N} \mathrm{ha}^{-1}$. However, there is no significant difference in the effect of different variants of PGRs application and the control in cv. Dorosa. 


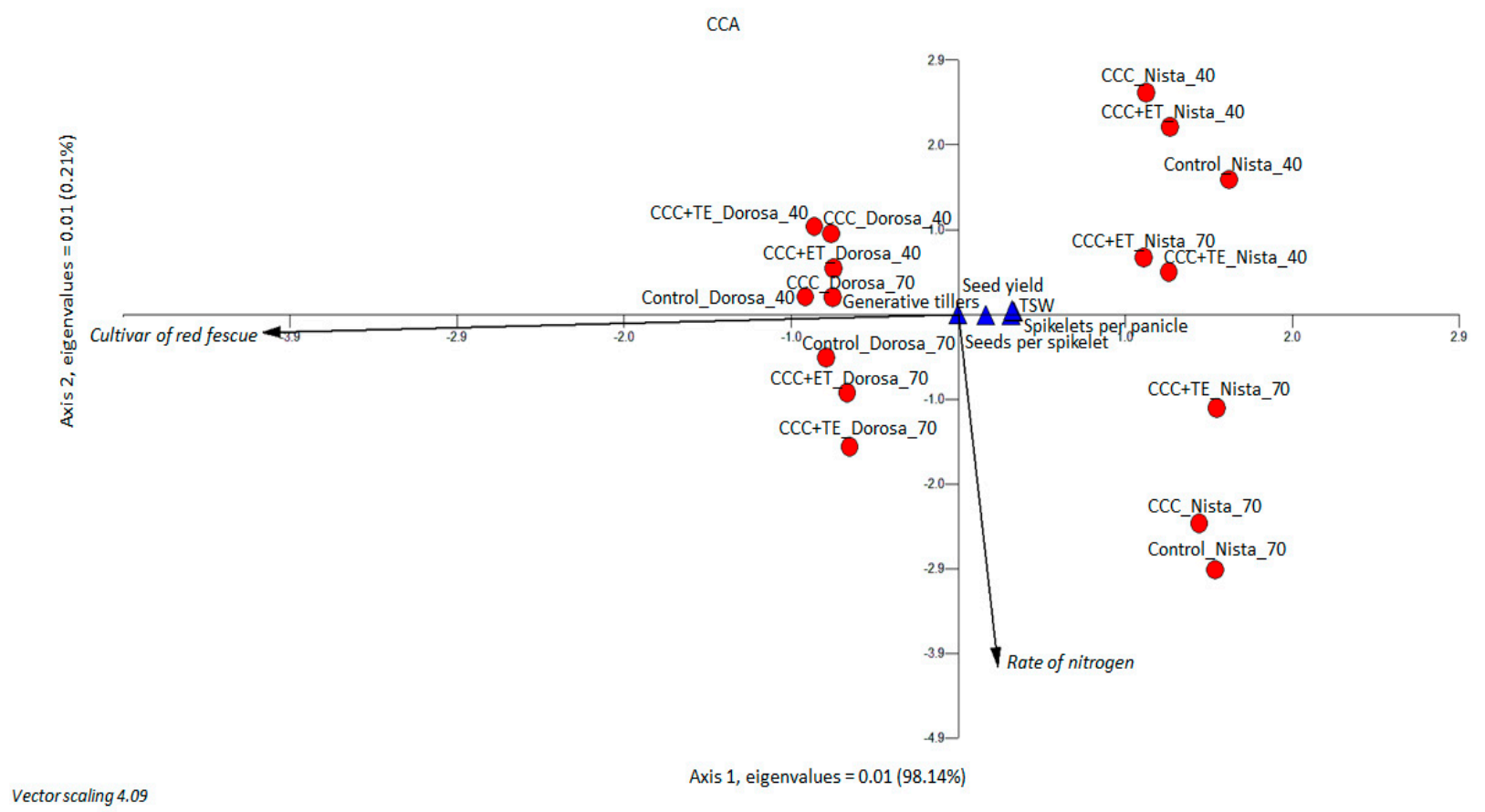

Figure 2. Canonical correspondence analysis (CCA) for seed yield, generative tillers, spikelets per panicle, seeds per spikelet and TSW of Festuca rubra ssp. rubra cv. Nista and F. r. ssp. commutata cv. Dorosa depending on plant growth regulator and nitrogen fertilization rate; eigenvalues for axis $1 \kappa=0.01(98.14 \%)$, for axis $2 \kappa=0.01(0.21 \%)$, significance of first axis: Monte Carlo-permutation test: (F-ratio $=4.23, p=0.001)$, significance of second axis: Monte Carlo-permutation test: $(\mathrm{F}-\mathrm{ratio}=1.03$, $p=0.135$ ).

\section{Discussion}

Red fescue treated with PGRs was characterized by a higher lodging index compared to the untreated one (Table 8). This was related to the effect of the preparations on the morphological traits of the cultivar's internodes (Table 6). All methods of PGRs application (CCC; CCC+ET; CCC+TE) caused shortening of the second internode of the cultivars, and the sequential use of CCC with ET or TE also shortened their third internode (Table 3). Correlation analysis indicated that increasing the fourth internode diameter or the wall thickness of the third or fourth internode led to an increase in the lodging resistance of the study plant (Table 6). However, this study showed only the effect of PGRs application on the second internode of the cultivars. Its diameter was greater than that of the control after CCC+TE was applied, as well as its wall thickness after CCC+ET application (Tables 4 and 5). Only a few studies on PGR application in red fescue indicate a small effect of PGR on the traits of the plant's internodes and its lodging. It has been shown that TE can reduce lodging only at increased doses [1,30]. In the study done by Mathiassen [30], there were no significant differences in the internode length of the plant, but the straw length of the untreated plant cultivars was only $60.4 \mathrm{~cm}$. In our study, this value was $73.4 \mathrm{~cm}$ [21]. A research on wheat enables a deeper understanding of the impact of PGRs on the morphological traits of plant's internodes and lodging. According to Zhang [31], the use of TE increased the stem strength (second basal internode), stem diameter, wall thickness, and also, enhanced lodging resistance at the anatomical level of the plants. Moreover, TE was extremely effective in reducing plant height. Rademacher [15] claims that TE inhibits the activity of enzyme 3-hydroxylase that transforms inactive gibberellins from GA20 into highly active forms of GA1 and GA3, which causes growth reduction and stem wall thickening. According to the study done by Wiersma [32], changes in plant height, straw strength and acid detergent lignin content following TE treatment may be the key mechanisms in explaining the effects of TE on lodging reduction. ET, in turn, had 
higher value in plant erectness than TE but did not differ in plant height, straw strength, acid detergent lignin, or acid detergent fiber content from TE.

The applications of PGRs (TE, CCC) during spring have been shown to improve seed yields of Lolium perenne L. [17], Dactylis glomerata L. [18,19] and Festuca arundinacea Schreb. [20]. In Festuca rubra L., application of TE increased the seed yield but the effect varied between years [1]. In the present study, the use of CCC or CCC+ET resulted in a significant increase in seed yield compared to the control, by 12.4 and $13.4 \%$, respectively (Table 8). The increase in the yield after the application of CCC+TE was 9.3\%. This PGR treatment also had a positive effect on the number of spikelets per panicle. Our previous research indicates a direct significant effect of the number of spikelets per panicle on seed yield of red fescue [7]. In the present study, each method of applying PGRs resulted in an increase in TSW (Table 9). Similarly, Zapiola et al. [33] reported that the application of TE (with the combination of open-field burn) on strong creeping red fescue increased its seed weight, thus contributing to higher seed yields.

According to Bitarafan et al. [1], lodging affects pollination and seed development in grass seed crops, leading to reducton in seed yield. According to Chastain et al. [34] the application of PGR (TE) in perennial ryegrass improved its seed set, which contributed to an increase in seed yield. In our study, the PGR applied reduced lodging, but there is no report on the number of seeds per spikelet (Tables 8 and 9). This may be due to high lodging index of the study plant (Table 8). Even in the control, the ratio of canopy height to tiller length was not less than $61.4 \%$. However the application of PGRs had a positive effect on seed yield (Table 8). Rolston at al. [18] and Mathiassen at al. [30] argued that a significant increase in the seed yield of red fescue despite the lack of significant effects on straw length suggests that TE had an influence on the physiological processes affecting yield. A study on the application of TE on wheat showed that TE increased leaf relative chlorophyll content of the plant [31]. TE applied on creeping bentgrass increased relative water content and chlorophyll content. TE-treated plants had increased growth rate and maintained constant canopy photosynthetic rate and photochemical efficiency, while these parameters decreased for the untreated control [35].

Our study showed no interaction effect between PGRs and spring $\mathrm{N}$ fertilizer rates (data not shown) on the seed yield of red fescue. Similarly, paclobutriazol (PGR) significantly improved the seed yield of Chewings red fescue regardless of the $\mathrm{N}$ rate applied in early spring [36]. On the other hand, different relationships were shown in the case of TE application [14]. Seed yield was the variable with a significant $N \times$ PGR interaction. The optimum N rate for the crops not treated with PGR was $34 \mathrm{~kg} \mathrm{~N} \mathrm{ha}^{-1}$ compared to $56 \mathrm{~kg} \mathrm{~N} \mathrm{ha}{ }^{-1}$ for crops sprayed with TE. In the present study, the increased rate of nitrogen fertilizer resulted in a significant increase in seed yield (9.9\%), due to a significant increase in the number of spikelets per panicle (by 10.8\%) (Tables 8 and 9). Moreover, the number of seeds per panicle was $14 \%$ higher after applying $70 \mathrm{~kg} \mathrm{~N} \mathrm{ha}^{-1}$ compared to $40 \mathrm{~kg} \mathrm{~N} \mathrm{ha}^{-1}$. Similarly, Yanovszky [37] proved that the number of seeds per panicle is the most important yield component affected by nitrogen fertilizer.

The results of the research in determining of the optimal model of red fescue by using nitrogen fertilizer are inconclusive. Young at al. [38], analyzing the nitrogen fertilizer applied during spring on Chewings red fescue in the range of $90-210 \mathrm{~N} \mathrm{ha}^{-1}$, showed that the nitrogen rate did not affect the yield of the seed in the first year of production, while $90 \mathrm{~N} \mathrm{ha}^{-1}$ rate was the most desirable in the second year of production. At this rate, an increase in the number of florets per spikelet and seeds produced was noted (no $0.001 \mathrm{~m}^{-2}$ ). It was also shown that seed yield was the greatest when $\mathrm{N}$ was applied at double-ridge stage (BBCH 30-31). According to Fairey [39] in order to maximize the yield from two years of full production of Festuca rubra var. rubra, a rate of 55 to $80 \mathrm{~kg} \mathrm{~N} \mathrm{ha}^{-1}$ is sufficient, to be applied each time during the fall prior to the harvest year. However, the yield obtained by Fairey [39] was lower than that of the present study (the average yield from two production years was not more than $395 \mathrm{~kg} \mathrm{ha}^{-1}$ ). 
In the present study, canonical correspondence analysis shows that the plant cultivars had a greater effect on seed yield and yield components, while the effect of the rate of spring nitrogen fertilizer ( 40 or $70 \mathrm{~kg} \mathrm{ha}^{-1}$ ) was of secondary importance (Figure 2). The seed yield of Chewings red fescue cv. Dorosa amounted to $1.16 \mathrm{Mg} \mathrm{ha}^{-1}$ and was significantly higher (by 29\%) than the yield of strong creeping red fescue cv. Nista. Cultivar Dorosa developed 1.8 times more generative tillers than cv. Nista. Other studies also demonstrated the dominant role of the number of generative tillers in shaping the seed yield of plants [40]. In turn, our earlier research [7] showed that the yield of Chewings red fescue seeds was significantly lower than that of strong creeping red fescue. However, the better yielding cultivar always developed more generative tillers as well as number of spikelets per panicle. Fairey [39] indicated significant varietal differences in the seed yield of creeping red fescue (Festuca rubra var. rubra). Cultivar Boreal gave yields of $514 \mathrm{~kg} \mathrm{ha}^{-1}$, and cv. Jasper produced $60 \%$ of Boreal. In the study by Young [38], the maximum seed yield of Chewings red fescue was $766 \mathrm{~kg} \mathrm{ha}^{-1}$.

In the present study, strong creeping red fescue cv. Nista was more susceptible to lodging than Chewings red fescue cv. Dorosa (Table 8). This was due to the longer second internode and the longer, pendulous panicle in cv. Nista. Moreover, it developed a large biomass of easily lodged vegetative tillers [21]. The elongation of the panicle and the increase in the number of vegetative tillers could also induce the intensification of the lodging under conditions of increased nitrogen fertilizer (from 40 to $70 \mathrm{~kg} \mathrm{ha}^{-1}$ ). The lack of PGR application had a greater effect on yield and yield components in cv. Nista, both when fertilized with 40 and $70 \mathrm{~kg} \mathrm{~N} \mathrm{ha}^{-1}$. However, there was no substantial difference between the impact of the different variants of the PGR application and the control in cv. Dorosa.

\section{Conclusions}

Red fescue treated with PGRs had significantly more lodging resistance than untreated one. This was mainly related to the effect of PGRs on internode length. Decreasing the second, third and fourth internodes lengths decreases lodging. All the methods of PGRs application (CCC; CCC+ET; $\mathrm{CCC}+\mathrm{TE})$ resulted in the shortening of the second internode, but only sequential application (CCC at BBCH 30-31 + ET or TE at BBCH 37-39) resulted in the shortening of the third internode. Increasing the diameter of the fourth internode as well as the wall thickness of the third and fourth internodes increases the lodging resistance, but the methods of PGRs application tested had no significant effect on these tiller traits. The use of PRGs had a beneficial impact on the yield of crop. Under low $\left(40 \mathrm{~kg} \mathrm{~N} \mathrm{ha}^{-1}\right)$ and medium rate $\left(70 \mathrm{~kg} \mathrm{~N} \mathrm{ha}^{-1}\right)$ nitrogen fertilization rates, the cultivar had a greater effect on the seed yield. A greater seed yield from the Chewing red fescue cv. Dorosa was obtained due to the large number of generative tillers. For a better understanding of the effects of PGRs on fescue seed yield, research is needed on the effect of application times and the type of PGRs under increasing rates of spring $\mathrm{N}$ fertilization.

Author Contributions: Conceptualization, M.S.; Methodology, M.S.; Formal Analysis, M.S.; Investigation, M.S. Data Curation, M.S., and M.B.; Writing-Original Draft Preparation, M.S., M.B., and R.G.; Writing-Review \& Editing, M.S., M.B., and R.G.; Visualization, M.S., and R.G.; Supervision, M.S., and R.G. All authors have read and agreed to the published version of the manuscript.

Funding: This research received no external funding.

Conflicts of Interest: The authors declare no conflict of interest.

\section{References}

1. Bitarafan, Z.; Rasmussen, J.; Westergaard, J.C.; Andreasen, C. Seed yield and lodging assessment in red fescue (Festuca rubra L.) sprayed with trinexapac-ethyl. Agronomy 2019, 9, 617. [CrossRef]

2. Braun, R.; Patton, A.J.; Watkins, E.; Koch, P.L.; Anderson, N.P.; Bonos, S.A.; Brilman, L.A. Fine fescues: A review of the species, their improvement, production, establishment, and management. Crop Sci. 2020, 60, 1142-1187. [CrossRef] 
3. Duru, M.; Cruz, P.; Magda, D. Using plant traits to compare sward structure and composition of grass species cross environment al gradients. Appl. Veg. Sci. 2004, 7, 11-18. [CrossRef]

4. Stukonis, V.; Juzenas, S.; Ceseviciene, J.; Norkeviciene, E. Assesment of morfo-anatomical traits of red fescue (Festuca rubra L.) germplasm differing in origin. Zemdirbyste 2015, 102, 437-442. [CrossRef]

5. De Vazquez Aldana, B.R.; Gundel, P.E.; Garcia Criado, B.; Garcia Ciudad, A.; Garcia Sanchez, A.; Zabalgogeacoa, I. Germination response of endophytic Festuca rubra seeds in presence of arsenic. Grass Forage Sci. 2013, 69, 462-469. [CrossRef]

6. Bertin, C.; Senesac, A.F.; Rossi, F.S.; DiTommaso, A.; Westo, L.A. Evaluation of selected fine-leaf fescue cultivars for their turfgrass quality and weed suppressive ability in field settings. HortTechnology 2009, 19, 660-668. [CrossRef]

7. Szczepanek, M.; Onofri, A. Chewing, strong and slender creeping red fescue response to sowing time and method. Crop Sci. 2013, 53, 2613-2622. [CrossRef]

8. Boelt, B. Undersowing Poa pratensis L., Festuca rubra L., Festuca pratensis Huds., Dactylis glomerata L., Lolium perenne L., for seed production in five cover crops. III. The effect of autumn applied nitrogen on seed yield of the undersown grasses. J. Appl. Seed Prod. 1997, 15, 55-61.

9. Macháč, R. Effects of trinexapac-ethyl (Moddus) on seed yields and its quality of eleven temperate grass species. In Breeding Strategies for Sustainable Forage and Turf Grass Improvement; Barth, S., Milbourne, D., Eds.; Springer: Berlin, Germany, 2013; pp. 359-363.

10. Baczyński, M.; Szczepanek, M.; Bech, A. Seed quality of red fescue (Festuca rubra ssp. rubra and F. r. ssp. commutata) depending on nitrogen fertilization and plant growth regulators. In Proceedings of the 14th Scientific and Technical Seminar on Seed and Seedlings, Prague, Czech Republic, 7 February 2019; pp. 186-192.

11. Chynoweth, R.J.; Moot, D.J. Seed growth of three perennial ryegrass cultivars sown on two dates and treated with trinexapac ethyl straw shortener. Grass Forage Sci. 2016, 72. [CrossRef]

12. Griffith, S.M. Changes in dry matter, carbohydrate and seed yield resulting from lodging in three temperate grass species. Ann. Bot. 2000, 85, 675-680. [CrossRef]

13. Haldrup, C. Growth regulation, fungicides and nitrogen interaction in seed crop production. In Proceedings of the 6th International Herbage Seed Conference, Giennestad, Norway, 18-20 June 2007; pp. 211-2013.

14. Young, W.C., III; Silberstein, T.B.; Chastain, T.G.; Garbacik, C.J. Response of creeping red fescue (Festuca rubra L.) and perennial ryegrass (Lolium perenne L.) to spring nitrogen fertility and plant growth regulator applications in Oregon. In Proceedings of the 6th International Herbage Seed Conference, Giennestad, Norway, 18-20 June 2007; pp. 201-205.

15. Rademacher, W. Growth retardants: Effect on gibberellin biosynthesis and metabolic pathways. Annu. Rev. Plant Biol. 2000, 51, 501-531. [CrossRef] [PubMed]

16. Rajala, A.; Peltonen-Sainio, P.; Onnela, M.; Jackson, M. Effects of applying stem-shortening plant growth regulators to leaves on root elongation by seedlings of wheat, oat and barley: Mediation by ethylene. Plant Growth Regul. 2002, 38, 51-59. [CrossRef]

17. Borm, G.E.L. Effects of the application rate and time of the growth regulator trinexapac-ethyl in seed crops of Lolium perenne L. in relation to spring nitrogen rate. Field Crops Res. 2008, 105, 182-192. [CrossRef]

18. Rolston, M.; Chynoweth, R.; Kelly, M.; McCloy, B.; Trethewey, J. Seed yield response of four cocksfoot (Dactylis glomerata L.) cultivars following the application of stem-shortening plant growth regulators. N. Z. J. Agric. Res. 2014, 53, 332-341. [CrossRef]

19. Rolston, M.; Trethewey, J.; Chynoweth, R.; McCloy, B. Trinexapac-ethyl delays lodging and increases seed yield in perennial ryegrass seed crops. N. Z. J. Agric. Res. 2010, 53, 403-406. [CrossRef]

20. Chastain, T.; Young, W.C., III; Garbacik, C.J.; Silberstein, T.B. Trinexapac-ethyl rate and application timing effects on seed yield and yield components in tall fescue. Field Crops Res. 2015, 173, 8-13. [CrossRef]

21. Szczepanek, M.; Stypczyńska, Z.; Dziamski, A.; Wichrowska, D. Above- and below-ground part growth in chewings and strong creeping red fescue grown for seed resulting from retardants and N fertilization. Agronomy 2020, 10, 4. [CrossRef]

22. Berthet, P.; Gerard, G. A statistical study of microdistribution of oribatei (Acari) Part I. The distribution pattern. Oikos 1965, 16, 214. [CrossRef]

23. Łomnicki, A. Introduction to Statistics for Naturalists, 4th ed.; PWN: Warsaw, Poland, 2010; p. 280. (In Polish)

24. Stanisz, A. Easy Course of Statistic Using Statistica PL and Medicine Examples, 1. Basic Statistic; StatSoft Polska: Krakow, Poland, 2006; p. 532. (In Polish)

25. Leps, J.; Smilauer, P. Multivariate Analysis of Ecological Data Using CANOCO; Cambridge University Press: Cambridge, UK, 2003; p. 283.

26. Piernik, A. Numerical Methods in Ecology; Wydawnictwo Naukowe UMK: Torun, Poland, 2008; p. 98. (In Polish)

27. Legendre, P.; Oksanen, J.; ter Braak, C.J.F. Testing the significance of canonical axes in redundancy analysis. Methods Ecol. Evol. Br. Ecol. Soc. 2011, 2, 269-277. [CrossRef]

28. Legendre, P.; Legendre, L. Numerical Ecology, 2nd ed.; Elsevier Science BV: Amsterdam, The Netherlands, $1998 ;$ p. 853.

29. Stanisz, A. Easy Course of Statistic Using Statistica PL and Medicine Examples, 2. Linear and Non-Linear Models; StatSoft Polska: Krakow, Poland, 2007; p. 868. (In Polish)

30. Mathiassen, S.K.; Rabolle, M.; Boelt, B.; Kudsk, P. Factors affecting the activity of Moddus M in red fescue. In Proceedings of the 6th International Herbage Seed Conference, Giennestad, Norway, 18-20 June 2007; pp. 169-171.

31. Zhang, Y.; Su, S.; Tabori, M.; Yu, J.; Chabot, D.; Baninasab, B.; Wang, X.; Ma, B.; Li, C.; Khanizadeh, S. Effect of selected plant growth regulators on yield and stem height of spring wheat in Ontario. J. Agric. Sci. 2017, 9, 30-42. [CrossRef] 
32. Wiersma, J.J.; Dai, J.; Durgan, B.R. Optimum timing and rate of trinexapac-ethyl to reduce lodging in spring wheat. Agron. J. 2011, 103, 864-870. [CrossRef]

33. Zapiola, M.L.; Chastain, T.G.; Garbacik, C.J.; Young, W.C. Trinexapac-ethyl and burning effects on seed yield components in strong creeping red fescue. Agron. J. 2014, 106, 1371-1378. [CrossRef]

34. Chastain, T.; Young, W.C., III; Silberstein, T.B.; Garbacik, C.J. Performance of trinexapac-ethyl on Lolium perenne seed crops in diverse lodging environments. Field Crops Res. 2014, 157, 65-70. [CrossRef]

35. McCann, S.E.; Huang, B. Effects of trinexapac-ethyl foliar application on creeping bentgrass responses to combined drought and heat stress. Crop Sci. 2007, 47, 2121-2128. [CrossRef]

36. Young, W.C.; Chilcote, D.O.; Youngberg, H.W. Chemical dwarfing and response of cool-season grass seed crops to spring-applied nitrogen. Agron. J. 1999, 91, 344-350. [CrossRef]

37. Janovszky, J. Effects of production factors on seed yield and yield components of red fescue (Festuca rubra ssp. genuine Hack). 2. Effects of production factors on panicle productivity. Cereal Res. Commun. 1994, 22, 211-217.

38. Young, W.C.; Chilcote, D.O.; Youngberg, H.W. Split-applied nitrogen and productivity of cool-season grass seed crops. Agron. J. 1999, 91, 339-343. [CrossRef]

39. Fairey, N.A. Cultivar-specific management for seed production of creeping red fescue. Can. J. Plant Sci. 2006, 86, 1099-1105. [CrossRef]

40. Fairey, N.A.; Lefkovitch, L.P. Crop density and seed production of creeping red fescue (Festuca rubra L. var. rubra). 1. Yield and plant development. Can. J. Plant Sci. 1996, 76, 291-298. [CrossRef] 